\title{
ACHIEVING POVERTY ALLEVIATION IN NIGERIA THROUGH MORTGAGE FINANCING Constraints and Way Forward
}

\author{
N. B. Udoekanem \\ Department of Estate Management \\ Federal University of Technology \\ Minna, Niger State, Nigeria \\ Email: namnsoudoekanem@futminna.edu.ng \\ doi:10.4314/gjds.v9i1.5
}

\begin{abstract}
This paper examines mortgage financing in Nigeria as an instrument for poverty alleviation. Data for the study were obtained from the Central Bank of Nigeria (CBN), the National Bureau of Statistics (NBS) and Federal Mortgage Bank of Nigeria (FMBN) and analyzed using descriptive statistical methods. It was found that mortgage financing in the country had not contributed significantly to poverty alleviation in the past five and a half decades due to factors, such as the poor capital base of the mortgage finance institutions resulting in inadequate loanable funds, difficulty in accessing available loanable funds by the low and middle income groups, high interest rates on available loanable funds which are unaffordable to the low and middle income groups, challenges of the Land Use Act of 1978 and the inconsistent financial policies of the Nigerian financial system. The paper concludes that the mortgage market in the country could be strengthened to act as an instrument for poverty alleviation and economic empowerment. It recommends the introduction of pro-poor mortgage facilities in the mortgage industry in Nigeria as such initiatives will economically empower the low and middle income groups in the country to invest in real estate through home ownership and thereby contribute to the alleviation of poverty.
\end{abstract}

Keywords: Pro-Poor Mortgage Facilities, Mortgage Finance, Poverty Alleviation, Real Estate, Financial Policies.

\section{INTRODUCTION}

The mortgage industry is an important component of a nation's economy as it facilitates the mobilization of financial resources, especially savings and deposits from surplus units in the economy for financing housing investment needs. Housing is a basic necessity of human beings. It accounts for a considerable portion of a nation's production activities through its, one: backward linkages to land markets, building material industries and labour markets, and two: forward linkages to financial markets (IFC, 2004). The provision of housing and other basic infrastructure require huge capital. Mortgage institutions mobilize savings and deposits and create mortgage loans to finance home ownership. It has been estimated by the Federal Mortgage Bank of Nigeria that Nigeria needs at least $\$ 56$ trillion to develop a minimum of 720,000 housing units annually in the next 20 years to meet its housing needs (FMBN, 2011b).

Experts in Nigeria's housing finance, including Adibua (1979); Uduehi (1985); Asaju (1993); Ajanlekoko (2001) and Ebie (2005) have argued that provision of housing for most of the income groups in Nigeria depends on the availability of capital, particularly long-term loans at reasonable interest rates. The provision of finance for the development of houses to meet the nation's housing needs requires a viable mortgage system in which savings and deposits are mobilized and such funds applied to create loans on mortgages for the purpose of home ownership without administrative and legal encumbrances. To this end, is there any significant progress in mortgage financing in Nigeria in the past five and a half decades? Are there constraints to mortgage financing in Nigeria? How can poverty alleviation be achieved in 
Nigeria through mortgage financing? What is the way forward? Answers to these questions form the basis of this paper.

The paper begins with the conceptual framework on the nexus between mortgage financing and poverty alleviation. This is followed by discussions on housing Nigeria's poor, the development of Nigeria's mortgage finance markets, its key players and their performance in mortgage financing in the country. The paper further discusses mortgage financing as a tool for achieving poverty alleviation in the country, the prospects and constraints as well as identifies measures necessary to overcome these constraints.

\section{THE NEXUS BETWEEN MORTGAGE FINANCING AND POVERTY ALLEVIATION}

In absolute terms, poverty is considered as lack of resources to consume some bundle of goods and services, a minimum of which comprise basic necessities such as food, shelter and clothing. According to Salmen (1992) as adopted by Sowa (2002), the absolute poor are those with income-per-person too low to afford 2,250 calories of food per day and are thus at risk of poverty-induced under-nutrition. Much earlier Townsend (1973) had conceived on relative poverty as a state where individuals and families are in command of resources which, over time, fall seriously short of the resources commanded by the average person or families in the community in which they live. In Nigeria, poverty is measured in absolute terms and considered the lack of resources to consume certain bundle of goods and services, including basic necessities such as food, shelter and clothing, among others (FOS, 1996).

In 2001, there were more than 1 billion people in the world living in poverty as defined by the frugal $\$ 1$ a day poverty measure (Chen \& Ravallion, 2004). There are also dramatic differences in poverty among countries, even among developing countries (Arestis \& Caner, 2009). With population growing at about the same rate as output, per capita income in Africa has remained stagnantly low for years even as majority of Africans live on less than $\$ 1$ a day (Sowa, 2002). Nigeria is the most populous country in Sub-Saharan Africa. With a total population of over 140 million people, its national absolute poverty rate is $78.3 \%$ (NBS, 2009).

According to Winters, McCulloch and McKay (2004), the alleviation of poverty is attained through long-term economic growth. They also argue that faster economic growth raises income levels, which in turn allows governments to earn more tax revenues and to take on redistributive measures. The nexus between mortgage financing and poverty alleviation occur through increased productivity. Thus, increased access to affordable mortgage finance for housing development will lead to increased employment in the building construction sector of the economy and consequently, economic growth. The presence of financial markets, including mortgage markets enhances economic welfare and growth through more efficient mediation between savers and investors (Levine et al, 1998). They also found that a well-developed financial system contributes at least 1 per cent of GDP growth.

Finance is the life-blood of the economic system and the financial system is the vessel that carries this life-blood through the economic system (Sowa, 2002). Availability of credit and savings facilities could help poor rural households manage and often augment their meager resources and acquire adequate food and other basic necessities for their families (Zellar and Sharma, 1998; Rutherford 1999). Mortgage financing can contribute to poverty reduction. In the context of macroeconomics, mortgage financing can lead to poverty reduction if growth is engendered in the economy (Sowa, 2002; Winters et al, 2004). Also, mortgage financing can lead to poverty alleviation if mortgage credit is available to the poor to improve their welfare through the provision of affordable housing. On this basis, this paper examines whether mortgage financing has contributed to poverty alleviation in Nigeria in the past few decades, the constraints to achieving poverty alleviation in the country through mortgage financing and the way forward. 


\section{HOUSING NIGERIA'S POOR}

Housing as an important basic necessity of human beings has been acknowledged worldwide. Inadequate accommodation is one of the major socio-economic problems facing Nigeria for several decades now. The policy objective of the federal government of Nigeria, over the years, has been the provision of housing to all classes of Nigerian citizens but its efforts are still nipped in the bud despite the various housing programmes embarked upon by it and other tiers of government in the country. Looking at the efforts made by each successive government towards the provision of affordable housing since the country's independence in 1960 till date, it is clear that such programmes have failed to deliver expected results.

For instance, the General Yakubu Gowon's administration established the National Housing Programme in 1972, which was the first of its kind in the history of Nigeria. This was followed by the establishment of the Federal Housing Authority (FHA) in 1973 as the sole agency with the responsibility of executing its approved housing programmes. This authority has succeeded in establishing its presence in a few cities, including Abuja, the Federal Capital Territory. Besides, most of its houses are meant for high income earners, who constitute a minute proportion of the homeless population. The federal government then sought to construct 59,000 housing units throughout the Federation of Nigeria but it failed to meet its target.

The Generals Mohammed Murtala and Olusegun Obasanjo regimes (1975-1979) came up with their own housing programmes with the aim of improving the overall quantity of comfortable and affordable houses for low-income earners in the country. During that period, a total of 202,000 housing units were to be provided by the government, but only $15 \%$ of the houses were completed and delivered. Again, the government failed to meet its target during this period. The provision of houses for the people as a priority continued during the administration of President Shehu Shagari (1979 - 1983). The target group was still the low-income group. A total of 410,000 housing units were to be constructed annually nationwide by the government, but only 32,000 housing units which represents about $7.8 \%$ of the estimated housing units required was achieved. This time, the government also failed to meet its target. The General Muhammadu Buhari regime (1983 - 1985) continued from where the Shagari administration stopped, yet no impact was created or felt.

The struggle for affordable housing for the masses continued with the General Ibrahim Babangida regime (1985 - 1993). It came up with a new National Housing Policy for the country in 1991 with the goal of ensuring that all Nigerians own or have access to decent housing at affordable cost by the year 2000.To meet that deadline, the federal government in 1991 planned to develop 850,000 housing units yearly. The government then failed to meet its target as it did not develop more than $5 \%$ of the estimated housing units before the end of the administration in August, 1993.

Other successive governments including those of General Sani Abacha (1993-1998), General Abdulsalami Abubakar (1998-1999), President Olusegun Obasanjo (1999-2007) and President Umaru Musa Yar Adua (2007-2010) also joined the struggle for solving the nation's acute housing problem with very little achievement.

The rapid population growth in the country has undoubtedly resulted in excessive increase in demand for housing and related basic services and infrastructures. Over the years, the housing situation in the country has been so serious with its associated problems such as high occupancy rate, difficulty in acquiring land, organic growth of slums and blighted areas, spiraling rents compared to the tenants' wage levels and large household size, among others. 


\section{DEVELOPMENT OF NIGERIA'S MORTGAGE FINANCE MARKETS}

Several scholars in the fields of real estate, banking, finance, development economics and business administration including Ifionu (1995) Chukwu (1997) and Ifediora (2000) have discussed extensively the development of the mortgage industry in Nigeria. However, three significant stages to the evolution of mortgage institutions in Nigeria can be identified. These are the pre-independence period (1900-1959), the post-independence period (1960-1985) and the period of deregulation (1986-present).

\section{Pre-independence period}

The development of mortgage institutions in Nigeria started during the colonial period when some institutions were established to provide funds for civil servants to build their own houses. Such institutions include the Colonial Development Corporation which later changed its name to the Commonwealth Development Corporation and the African Staff Housing Fund. However, organized and formal mortgage financing in Nigeria commenced in 1956 when the Nigerian Building Society (NBS) was established (Oni, 2005). The NBS was a joint venture between the Commonwealth Development Corporation, the Federal Government of Nigeria and the then Eastern Regional Government. Its major function was to provide mortgage loans to deserving Nigerians. During this period, the foundation for formal mortgage system in the country was laid by the colonial authorities. The period also witnessed the development of housing estates for civil servants of African origin within the low-income class, through funds from the Commonwealth Development Corporation.

\section{Post-independence period}

This period witnessed significant progress in mortgage financing in Nigeria. The Federal Mortgage Bank of Nigeria (FMBN) was established in 1977 to inherit the assets and liabilities of the NBS. The initial capital base of the FMBN was $\$ 20$ million and in 1979, it was increased to 100 million. As reported by Omotosho (2005), the FMBN took over more than 3,200 mortgage loans and undisbursed commitments with a total value of $\$ 100$ million, comprising 75 million in mortgage assets and undisbursed commitments making up the total from the NBS. The primary functions of the FMBN as outlined in the FMBN Act of 1977 include provision of long term credit to mortgage institutions for on-lending to individuals for acquiring houses of their own, encouragement and promotion of the development of mortgage institutions, provision of long term credit directly to individuals for home ownership and provision of credit for housing estate and commercial property development purposes.

At the initial stage, the FMBN combined primary mortgage functions with its regulatory role to fill the gap created by the non-existence of primary mortgage institutions. This period also witnessed strict regulation of the financial sector of the economy, including the mortgage subsector. Regulation during this period involved strict adherence to the credit policies of the Central Bank of Nigeria by financial institutions in the country, including deposit money banks which grant mortgage loans. The then commercial and merchant banks were required by the Central Bank of Nigeria to allocate a stipulated minimum proportion of their credit to the housing sector (Sanusi, 2003). Thus, 5\% of total loans and advances was the minimum stipulated for banks in the 1979/80 fiscal year and it was increased to $6 \%$ and 13\% in 1980 and 1982 respectively. However, where the stipulated target was not met by banks, such shortfalls were deducted at source from the defaulting bank's deposit with the Central Bank of Nigeria and passed on to the housing sector through the Federal Mortgage Bank of Nigeria (FMBN). 


\section{Period of deregulation}

Prior to 1986 when the Structural Adjustment Programme (SAP) was adopted, the federal government fixed the level and structure of interest rate. According to Alade and associates (2003), the major reasons for regulating interest rates were the desire to obtain the social optimum in resource flow to the preferred sectors of the economy, promote an orderly growth of the financial markets, combat inflation and lessen government's debt burden. The financial sector reforms relied on market forces, resulting in the liberalization of the sector and consequently, the deregulation of interest rates. As argued by Ifionu (1995), this affected the mortgage industry, resulting in increased demand for mortgage loans from the Federal Mortgage Bank of Nigeria as interest rate on loans granted by commercial banks and other financial institutions increased.

In 1989, the Mortgage Institutions Act was enacted to facilitate the establishment of Primary Mortgage Institutions (PMIs) in order to provide a safe and convenient means of saving for the general public, corporate and unincorporated bodies and to use the funds to make loans on mortgages, primarily to those who wish to buy or build their own homes. The Act provided the basis of the structure of the mortgage industry in Nigeria. Primary Mortgage Institutions (PMIs) came into existence in the country during this period as the Federal Mortgage Bank of Nigeria commenced their licensing in 1991. However, for a mortgage system to be efficient and viable, long term loanable funds at affordable interest rates is necessary. To achieve this and to insulate the mortgage system from the syndrome of paucity of long term funds that had curtailed the expansion of mortgage lending services, the National Housing Fund (NHF) was established through the National Housing Fund Act of 1992. As at January 2012, the number of houses built through NHF operations is presented in Table 1.

Table 1: Number of houses built through NHF operations in Nigeria, $1992-2012$

\section{Indicators}

Loans

Houses built with Estate Development Loan

Houses financed with Mortgage Buy-Back

Total Housing units built
Cumulative as at January, 2012

Houses built with NHF

18,668

32,950

9,575

61,193

Source: FMBN (2012)

It has been estimated that Nigeria has a housing deficit of about 16 million housing units (FMBN, 2011b). Based on an average occupancy rate of 7 persons per house (NBS, 2009), about 112 million Nigerians are homeless considering the current housing deficit in the country. This implies that $80 \%$ of Nigerians are without shelter. This proportion is related to the national absolute poverty rate of $78.3 \%$ (NBS, 2009). As shown in Table 1, a total of 61,193 houses were built in the country through the NHF operations as at January 2012, since its inception in 1992. This represents an infinitesimal proportion of $0.38 \%$ of the nation's current housing deficit. These houses were sold at target prices of $\$ 1.0$ million $(\$ 6,024)$ to $\$ 5.0$ million $(\$ 30,120)$. Based on World Bank's estimate which shows that $70.2 \%$ of the total population in Nigeria lives on an income of less than US\$1 a day (NPC, 2004), these houses are unaffordable to the poor, which constitute majority of the country's homeless population.

\section{KEY PLAYERS IN NIGERIA'S MORTGAGE FINANCE MARKETS}

The mortgage industry in Nigeria has remained oligopolistic with a few institutions providing mortgage financing and building houses (Ebie, 2005). Mortgage transactions in Nigeria are based on products from two groups of financial institutions. The first group consists of the core 
mortgage institutions, comprising the Federal Mortgage Bank of Nigeria and Primary Mortgage Institutions (PMIs). The other group comprises non-core mortgage institutions which grant mortgage loans at market interest rates such as commercial banks and insurance companies.

Based on the provisions of the Mortgage Institutions Act of 1989, a mortgage institution is defined as any company licensed to carry out a mortgage business under the Act and make available mortgage loans and advances for purchase, construction, improvement and extension of dwelling houses. Thus, apart from the Federal Mortgage Bank of Nigeria and Primary Mortgage Institutions, Deposit Money Banks (DMBs) and insurance companies also mobilize deposits from the public and grant loans and advances to individuals and corporate bodies for the acquisition of houses. Hence, deposit banks and insurance companies are key players in the mortgage industry in Nigeria (Alade et al, 2003; Sanusi, 2003 and Omotosho, 2005).

\section{Federal Mortgage Bank of Nigeria (FMBN)}

The FMBN was established by the Federal Government in 1977 to provide long term credit to Nigerians for home ownership at affordable interest rate. Although it was originally established as the apex mortgage bank in the country, it assumed this status in 1989 when the Mortgage Institutions Act empowered it to license and regulate PMIs. In 1992, it was saddled with a new role of managing the National Housing Fund (NHF) based on the provisions of the NHF Act of 1992. Prior to 1992, the funding of the operations of the Federal Mortgage Bank of Nigeria had largely been through equity and loan capital from the Federal Government and the Central Bank of Nigeria. Since 1992, the bulk of the FMBN funds have been from contributions to the NHF. As reported by Omotosho (2005), the FMBN received \$722million applications in 1981, out of which it approved $\$ 125$ million and disbursed $\$ 75$ million. Similarly, applications amounted to $\$ 155$ million in 1982, out of which \$65million was approved and $\$ 51$ million was disbursed. Applications received by the FMBN in 1983 amounted to $\$ 184$ million, out of which \$88million was approved and $\$ 58$ million was disbursed.

Also, the average yearly applications received by the bank for the period 1981-1990 was over \#200million, compared with the average capital inflow of \$67million per annum. This was grossly inadequate compared with the growing demand for mortgage loans in the country. For this reason, the National Housing Fund (NHF) was established in 1992 to create a pool of funds to the FMBN to meet the demand for mortgage credit in Nigeria. To a large extent, this has not been achieved due to administrative, legal and related constraints. In the first five years of operation of the NHF (1992-1997), the FMBN did not disburse the NHF to contributors until the second quarter of 1997. During this period, 16,157 employers and 1,285,157 employees were registered for the NHF and contribution to the fund increased from $\$ 18.471$ million in the initial two years of operation to over 2 billion by December 1997(FMBN, 1997). As at January 2012, the cumulative collections of NHF stood at $\$ 81,596,557,806.41$ while the total cumulative loan disbursement stood at 83,217,918,705.01(FMBN, 2012).

\section{Primary Mortgage Institutions}

The promulgation of the Mortgage Institutions Decree (now Act) of 1989 empowered the FMBN to license and register PMIs to operate as retail mortgage lenders. The first set of PMIs were licensed in 1991 and by 1993, 252 PMIs had been licensed. This was further increased to 280 in 1995. In 1997, the licensing of PMIs was transferred from FMBN to Central Bank of Nigeria. The number of PMIs licensed to carry out mortgage financing business in Nigeria for the period 1991 to 2008 as presented in Table 2 . 
Table 2: Number of Primary Mortgage Institutions in Nigeria, 1991-2008

\begin{tabular}{|c|c|c|c|c|c|}
\hline Year & No. of PMIs a & Growth Rate (\%) ${ }^{\mathrm{b}}$ Yeal & r No. of PMIsa & \multicolumn{2}{|c|}{ Growth Rate (\%) ${ }^{b}$} \\
\hline 1991 & 23 & - & 2000 & 194 & - \\
\hline 1992 & 145 & 530.4 & 2001 & 79 & -59.3 \\
\hline 1993 & 252 & 73.8 & 2002 & 80 & 1.3 \\
\hline 1994 & 279 & 10.7 & 2003 & 81 & 1.3 \\
\hline 1995 & 280 & 0.36 & 2004 & 83 & 2.5 \\
\hline 1996 & 186 & -33.6 & 2005 & 90 & 8.4 \\
\hline 1997 & 115 & -38.2 & 2006 & 91 & 1.1 \\
\hline 1998 & 194 & 68.7 & 2007 & 93 & 2.2 \\
\hline 1999 & 194 & - & 2008 & 81 & -12.9 \\
\hline
\end{tabular}

Source: a Central Bank of Nigeria (2008)

b Computed from a

The trend in the growth of PMIs in the country during this period is shown in Figure 1.0.

Figure 1.0: The growth of Primary Mortgage Institutions in Nigeria (1992-2008)

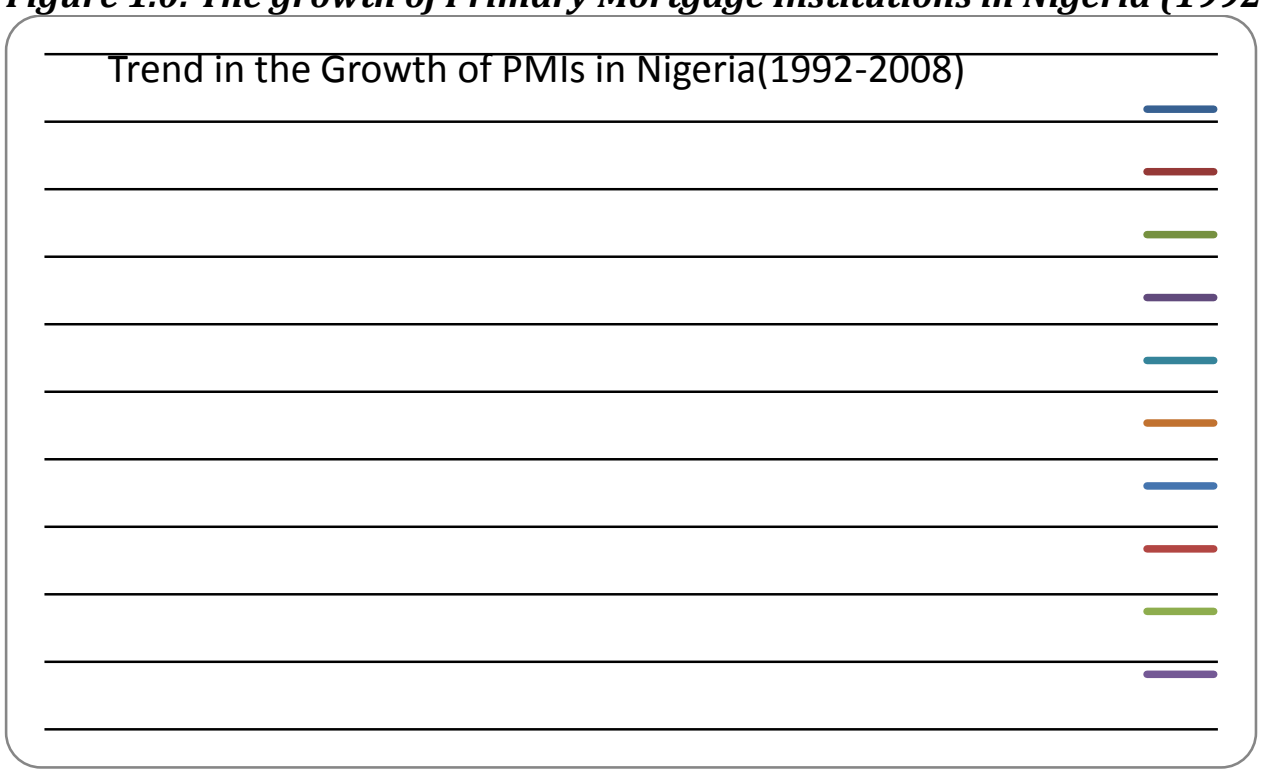

The number of PMIs in the country increased from 23 in 1991 to 145 in 1992, representing a growth rate of $530.4 \%$ as presented in Table 2 . This astronomical increase was due to the establishment of the NHF in 1992 by the federal government and consequently, more PMIs were needed as retail mortgage lenders for the disbursement of the fund. The period $1995-2001$ witnessed significant decline in the growth of PMIs in the country as the number of licensed PMIs dropped from 280 in 1995 to 194 in 1999 and further declined to 89 in 2001. This decline was due to the distress in the banking sector in the country and the banking reforms introduced by the federal government within the period through the enactment and implementation of the Banking and Other Financial Institutions Act (BOFIA) of 1995. The increase in the minimum paid up share capital of PMIs from $\$ 100$ million to 1 billion by the Central Bank of Nigeria in 2005 contributed to the withdrawal of licenses of those PMIs which could not recapitalize to the required capital base and further declined the number of PMIs from 90 in 2005 to 81 in 2008. Table 3 below shows mortgage loans of PMIs in Nigeria and performance indicators for the period (1992 - 2008). 
Table 3: Mortgage Loans of PMIs in Nigeria by year and performance indicators (19922008)

\begin{tabular}{llllllc}
\hline Year & $\begin{array}{l}\text { Mortgage } \\
\text { Loan ( N'm) }\end{array}$ & $\begin{array}{c}\text { Total Assets } \\
\text { ( N'm) }\end{array}$ & $\begin{array}{l}\text { Liquid } \\
\text { Assets(N'm) }\end{array}$ & $\begin{array}{l}\text { Current } \\
\text { Liabilities } \\
\text { (N'm) }\end{array}$ & $\begin{array}{l}\text { Liquidity } \\
\text { Ratio(\%) }\end{array}$ & $\begin{array}{c}\text { Loans to } \\
\text { Desit Ratio } \\
\text { (\%) }\end{array}$ \\
\hline 1992 & 208.90 & $2,243.20$ & 475.90 & $6,891.80$ & 6.90 & 3.20 \\
1993 & 334.70 & $3,610.70$ & 682.20 & $2,144.20$ & 31.80 & 21.20 \\
1994 & 560.30 & $3,070.30$ & 842.60 & $1,258.10$ & 67.00 & 53.70 \\
1995 & 394.90 & $2,951.80$ & 679.20 & $1,247.90$ & 54.40 & 35.80 \\
1996 & 754.80 & $4,388.60$ & 485.20 & $2,920.30$ & 16.61 & 30.32 \\
1997 & 738.00 & $6,078.90$ & $2,513.30$ & $4,534.10$ & 55.43 & 17.72 \\
1998 & 785.90 & $6,593.20$ & $2,714.70$ & $4,726.10$ & 57.44 & 18.12 \\
1999 & 924.20 & $7,656.30$ & $3,359.50$ & $4,998.60$ & 67.21 & 20.11 \\
2000 & 855.05 & $7,124.75$ & $3,037.10$ & $4,862.35$ & 62.46 & 19.14 \\
2001 & $1,024.65$ & $7,982.79$ & $3,372.33$ & $1,727.75$ & 195.19 & 75.63 \\
2002 & $6,600.62$ & $55,000.00$ & $23,445.10$ & $37,535.37$ & 62.46 & 19.14 \\
2003 & $12,895.56$ & $64,400.00$ & $45,804.44$ & $38,149.93$ & 120.06 & 35.69 \\
2004 & $6,000.00$ & $81,200.00$ & $41,408.62$ & $73,981.30$ & 55.97 & 9.29 \\
2005 & $2,100.00$ & $99,900.00$ & $52,420.95$ & $89,840.20$ & 58.35 & 2.69 \\
2006 & $7,560.00$ & $114,454.51$ & $51,813.94$ & $88,190.35$ & 58.75 & 9.12 \\
2007 & $40,759.40$ & $302,278.00$ & $29,956.10$ & $164,597.90$ & 18.20 & 26.14 \\
2008 & $97,150.00$ & $293,251.40$ & $28,094.50$ & $172,084.90$ & 16.33 & 60.94 \\
\hline
\end{tabular}

Source: Central Bank of Nigeria (2008)

As presented in Table 3 above, total loans granted by PMIs in 1992 stood at $\$ 208.9$ million. This rose to $\$ 738$ million in 1997 and further increased to $\$ 12.89556$ billion in 2003 . As at 2008, the total loans granted by PMIs in Nigeria amounted to $\$ 97.150$ billion. This trend indicates gradual growth in retail mortgage lending in the country. Experts in mortgage banking believe the PMIs would have made greater progress in the mortgage industry if they fully understand the nature of mortgage business which they are licensed to operate. Akinwale (2005) attributed the failure of the early primary mortgage institutions in Nigeria to this factor and reported as follows:

The early PMIs had gone into business without observing any of the tenets of financial planning and control. In fact, it was discovered that most promoters of PMIs had very little knowledge of what mortgage business was all about. Some promoters had the intention of finding an easy way of entering the banking industry but without any regard for the specialised nature of the mortgage business which PMIs are licensed to operate. A few other promoters even thought that the National Housing Fund scheme was another form of funding mechanism that would be allocating funds to the PMIs without any consideration for underwriting principles. Such misconceptions led to the early collapse of many PMIs.

However, there is need to strengthen the primary mortgage market to facilitate continuous flow of loanable funds for retail mortgage lending in the country.

\section{Deposit Money Banks}

Commercial banks are basically involved in financial intermediation. They usually lend on shortterm basis and are concerned with the security, liquidity, opportunity cost and inflation hedge of their capital. An important activity of commercial banks is that, they buy funds from the investing public through deposits and sell the funds by granting loans (Chukwu, 1997). Due to 
the high demand on their deposits at very short notice, many commercial banks are not interested in long-term lending. This is contrary to the long-term nature of mortgage finance. The failure of the mortgage finance institutions in mobilizing adequate finance for mortgage lending in Nigeria has resulted in increased demand for mortgage loans from commercial banks in the country (Udoekanem, 2010). In 2001, the Central Bank of Nigeria adopted universal banking practice. Thus, commercial and merchant banks became Deposit Money Banks (DMBs) from this date. Real estate and construction loans granted by commercial and merchant banks in Nigeria for the period 1981-1993 and 2008 are presented in Table 4.

Table 4: Real Estate and Construction Loans granted by Commercial and Merchant Banks in Nigeria, 1981-1993 and 2008

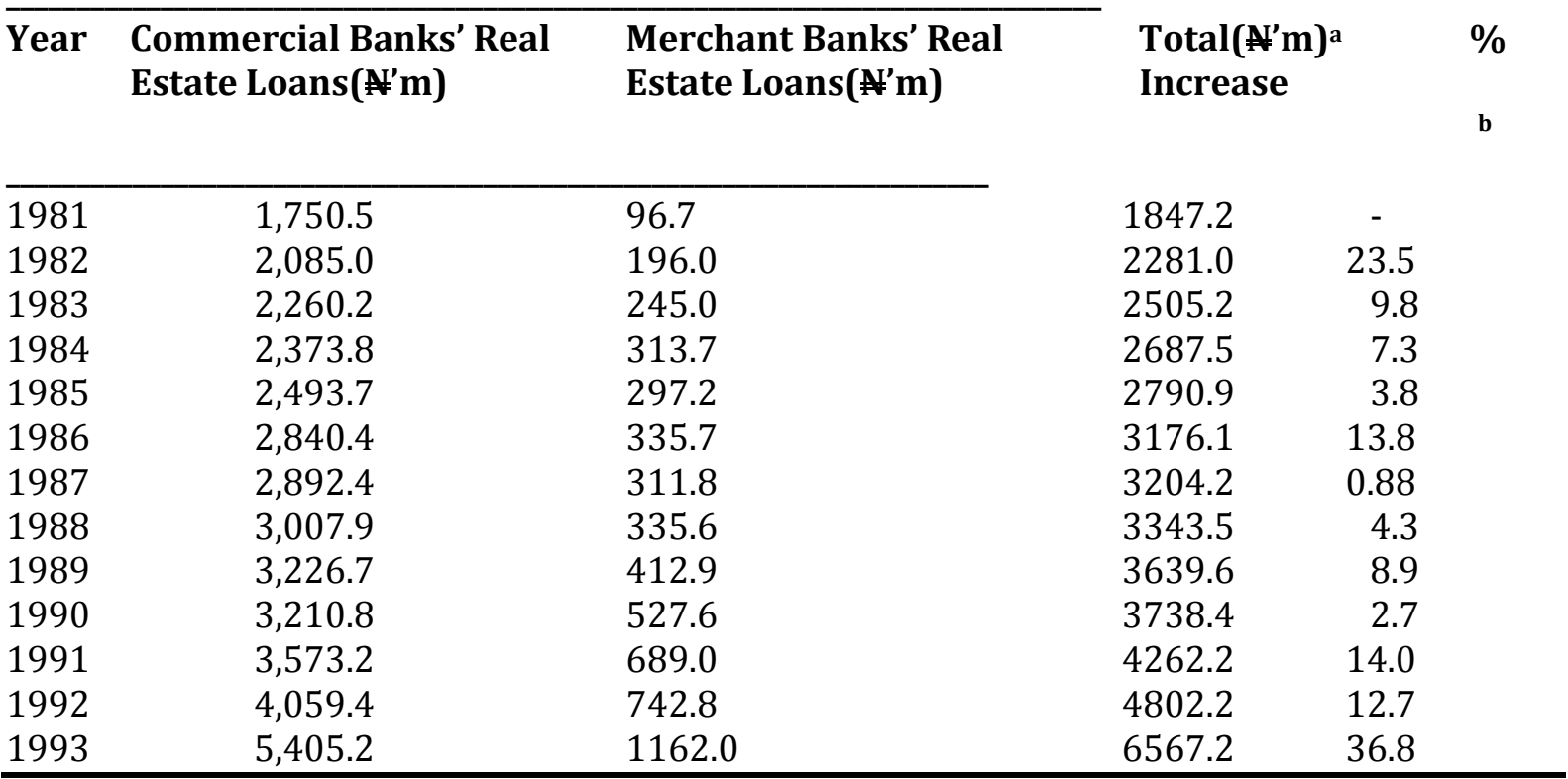

Source: a Central Bank of Nigeria (2005); ${ }^{b}$ Computed from a

As presented in Table 4, there has been continuous increase in real estate and construction loans granted by deposit money banks in the country since 1981. The average rate of increase in these loans for the period $1981-1993$ is $8.47 \%$. This was determined using geometric mean model. The total real estate loans granted by DMBs in the country also increased from 6567.2 million in 1993 to 456, 225. 6 million; as at December 2008 (NBS, 2009). This astronomical increase has been attributed to increased demand for real estate loans from DMBs by real estate developers for housing development in the country (Udoekanem, 2010).

\section{Insurance Companies}

Insurance companies are fund mobilizers and important source of capital fund for the economy (Sanusi, 2003). Insurance companies have also been active in mortgage financing in Nigeria. The investments of insurance companies on real estate and mortgage in Nigeria in the past few years are presented in Table 5. 
Table 5: Insurance Companies' Investment on Real Estate and Mortgage in Nigeria, 20032007

\begin{tabular}{lllll}
\hline Year & $\begin{array}{c}\text { Real Estate and } \\
\text { Mortgage(N'm) } \\
\text { Investments(\%) }\end{array}$ & $\begin{array}{l}\text { Total Investments } \\
\text { (N'm) }\end{array}$ & $\begin{array}{l}\text { \% of Real Estate to } \\
\text { Total Investments }\end{array}$ & $\begin{array}{l}\text { Growth in Real } \\
\text { Estate }\end{array}$ \\
2003 & $\begin{array}{c}\text { a } \\
\text { 14,272.79 }\end{array}$ & $54,642.84$ & 26.12 & b \\
2004 & $21,832.18$ & $74,590.75$ & 29.27 & - \\
2005 & $33,788.15$ & $121,844.22$ & 27.73 & 52.96 \\
2006 & $45,186.77$ & $216,359.91$ & 20.89 & 33.76 \\
2007 & $45,331.91$ & $329,247.93$ & 13.77 & 0.32 \\
\hline
\end{tabular}

Source: a National Bureau of Statistics (2009)

${ }^{\mathrm{b}}$ Computed from a

The investments of insurance companies on real estate and mortgage in Nigeria have increased significantly in the past few years at an average rate of $26 \%$. Again, this increase is needed to meet the demand for real estate credit in the country.

Generally, there has been continuous increase in the amount of mortgage loans granted by mortgage finance institutions in the country in the past decade. Thus, mortgage loans granted by PMIs increased at an average rate of $93.06 \%$. Similarly, those of deposit money banks and insurance companies increased at an average rate of $8.47 \%$ and $26 \%$ respectively. From the foregoing, PMIs stimulated the mortgage markets in the country within the period with more funds than other mortgage institutions. Hence, there is need for the government at all levels in Nigeria to sustain the operations of PMIs in the country to enhance efficient retail mortgage lending in the country.

\section{MORTGAGE FINANCING AS A TOOL FOR POVERTY REDUCTION}

Mortgage financing in Nigeria has not contributed much to poverty alleviation in the country. This can be examined in the context of availability of loanable funds, accessibility to loanable funds and affordability of loanable funds by the poor. The basis of these indicators is that they have been used consistently in measuring the performance of financial markets in Nigeria (Alade et al, 2003).

\section{Availability of loanable funds}

A measure of loanable funds is the amount of savings mobilized from the surplus sectors of the economy by financial intermediaries (Alade et al, 2003). As presented in Tables 2, 3 and 4, the amount of mortgage loans granted by primary mortgage institutions, deposit money banks and insurance companies has increased tremendously. Despite this, the contribution of mortgage loans and advances to the Gross Domestic Product (GDP) in Nigeria has been very low, compared to other economies. The ratio of mortgage loans and advances to the Gross Domestic Product (GDP) is a measure of the contribution of mortgage to economic growth of a nation. The ratio of mortgage loans and advances to GDP is $0.001 \%$ in Nigeria, $50 \%$ in the United States, $60 \%$ in the United Kingdom, 55\% in Europe and 35-40\% in Asia (Omotosho, 2005). Compared to other economies of the world, Nigeria's statistics on ratio of mortgage loans and advances to GDP implies that mortgage loans granted by financial institutions in the country are inadequate to make significant contribution to economic growth. Economic growth is one of the drivers of poverty alleviation and economic empowerment. Availability of loanable funds to the poor has been a critical issue in the Nigerian mortgage markets since the development of formal mortgage finance system in the country. The federal government attempted to tackle this issue 
in 1992 when it established the NHF to provide long-term funds for housing delivery by lowincome income earners. As at January 2012, the total number of contributors to the fund, total amount collected and other indicators are presented in Table 6.

\section{Table 6: Total number of contributors to the NHF, total amount collected and other indicators, 1992-2012}

\begin{tabular}{lc}
\hline Indicators & Cumulative as at January, 2012 \\
& \\
\hline NHF Registered Contributors & $3,657,354$ \\
NHF Collection & $81,596,557,806.41$ \\
Refund & $\$ 1,307,084,280.59$ \\
No. of Refund Cases & 68,035 \\
NHF Available to contributors & $80,289,473,525.82$
\end{tabular}

Source: $F M B N(2012)$

However, the lofty objectives of the NHF have not been achieved almost two decades after the fund was established due to some constraints bedeviling the administration of the fund. Consequently, some contributors have withdrawn from the NHF scheme and have applied and obtained the refund of their contributions. As shown in Table 6, the number of refund cases and the total amount refunded as at January 2012 stood at 68,035 and $\$ 1.307$ billion respectively. Thus, the total amount available to active contributors to the NHF is $\$ 80.289 \mathrm{billion}$. This is grossly inadequate for mortgage financing in the country when compared with the $\$ 56$ trillion required for financing the nation's housing deficit.

\section{Accessibility to loanable funds}

Available loanable fund can only be utilized if it is accessed by borrowers. Most mortgage institutions and deposit money banks in Nigeria are more concerned with the financial viability objectives of their operations than social development objectives and as such their requirements for mortgage lending do not suit the needs of the poor. The security for most mortgage loans in Nigeria is interest in real property. Such interest must be evidenced by a Certificate of Occupancy issued based on the provisions of the Land Use Act of 1978. Also, the Governor's consent is required for every mortgage transaction in the country. The processing of these documents has been found to be expensive (Udoekanem, 2008), slow and difficult (Udoekanem, 2009) and out of reach of the poor.

\section{Affordability of loanable funds}

In order to alleviate poverty and achieve economic empowerment, mortgage loans granted by mortgage institutions and other financial intermediaries must be affordable to all segments of income earners. In other words, it must be all-inclusive (Kajimo-Shakantu, 2006). Affordability of mortgage loan implies the ability of borrowers to pay the costs of loan without imposing constraints on living costs. It is the notion of reasonable mortgage loan costs in relation to income, that is, mortgage loan costs that leave borrowers with sufficient income to meet other basic needs such as food, rent, clothing, transport, medical care, education, among others.

In Nigeria, mortgage institutions and commercial banks grant mortgage loans based on a maximum repayment to income ratio (RTI) of 33.33 per cent, that is, not more than one-third of the borrower's monthly income is used for servicing the loan (Adeniji, 2005).This is the requirement of Section 5(3) of the terms and conditions for obtaining loans from the National Housing Fund by Mortgage Institutions and Individual Contributors Regulations(1996). Affordability of mortgage loans granted by mortgage institutions in Nigeria is skewed in favour 
of the high and middle income earners (Ebie, 2005; Oni, 2005). Even the National Housing Fund that was established to facilitate access to mortgage loan by the low-income group is no less different. At an interest rate of $6 \%$, the affordability level on the National Housing Fund is presented in Table 7.

Table 7: Affordability Level for Loans Granted from the National Housing Fund by Mortgage Institutions in Nigeria

\begin{tabular}{|c|c|c|c|c|c|c|}
\hline \multicolumn{2}{|c|}{$\begin{array}{l}\text { Loan Amount } \\
\text { in } N^{\prime} \text { million }\end{array}$} & \multicolumn{3}{|c|}{ Tenor and Monthly Loan Repayments } & \multirow[b]{2}{*}{ 25years } & \multirow[b]{2}{*}{ 30yrs } \\
\hline & 5 yrs & 10years & 15 years & 20years & & \\
\hline 1.0 & $19,332.80$ & $11,102.05$ & $8,436.57$ & $7,164.31$ & $6,443.01$ & $5,995.51$ \\
\hline 1.25 & $24,166.00$ & $13,877.56$ & $10,548.21$ & $8,955.39$ & $8,053.77$ & $7,494.38$ \\
\hline 1.5 & $28,999.20$ & $16,653.08$ & $12,657.85$ & $10,746.47$ & $9,664.52$ & $8,993.26$ \\
\hline 1.75 & $33,832.40$ & $19,428.59$ & $14,767.49$ & $12,537.54$ & $11,275.27$ & $10,492.13$ \\
\hline 2.0 & $38,665.60$ & $22,204.10$ & $16,877.14$ & $14,328.62$ & $12,886.03$ & $11,991.01$ \\
\hline 2.25 & $43,498.60$ & $24,979.51$ & $18,986.78$ & $16,119.70$ & $14,496.78$ & $13,489.89$ \\
\hline 2.5 & $48,332.00$ & $27,755.13$ & $21,096.42$ & $17,910.78$ & $16,107.54$ & $14,988.76$ \\
\hline 2.75 & $53,165.20$ & $30,530.64$ & $23,206.05$ & $19,701.85$ & $17,718.28$ & $16,487.64$ \\
\hline 3.0 & $57,998.40$ & $33,306.15$ & $25,315.70$ & $21,492.93$ & $19,329.04$ & $17,986.52$ \\
\hline 3.25 & $62,831.60$ & $36,081.66$ & $27,425.35$ & $23,284.01$ & $20,939.80$ & $19,485.39$ \\
\hline 3.5 & $67,664.81$ & $38,857.18$ & $29,534.99$ & $25,075.09$ & $22,550.56$ & $20,984.27$ \\
\hline 3.75 & $72,498.01$ & $41,632.69$ & $31,644.63$ & $26,866.16$ & $24,161.30$ & $22,483.14$ \\
\hline 4.0 & $77,331.21$ & $44,408.20$ & $33,754.27$ & $28,657.24$ & $25,772.06$ & $23,982.02$ \\
\hline 4.25 & $82,164.41$ & $47,183.71$ & $35,863.92$ & $30,448.32$ & $27,382.81$ & $25,480.90$ \\
\hline 4.5 & $86,997.61$ & $49,959.23$ & $37,973.56$ & $32,239.40$ & $28,993.56$ & $26,979.77$ \\
\hline 4.75 & $91,830.81$ & $52,734.74$ & $40,083.20$ & $34,030.48$ & $30,604.32$ & $28,478.65$ \\
\hline 5.0 & 96.664 .01 & $55,510.25$ & $42,192.84$ & $35,821.55$ & $32,215.07$ & $29,977.53$ \\
\hline
\end{tabular}

Source: $F M B N$ (2011a)

Data obtained from the National Bureau of Statistics (2009) reveal that $75.2 \%$ of households in Nigeria earn monthly income of between $\$ 1,000$ and $\$ 20,000$ as presented in Table 8.

Table 8: Percentage Distribution of Households' Monthly Income in Nigeria

Monthly Income ( ) Percentage Distribution

\begin{tabular}{lc}
\hline $1,000-20,000$ & 75.2 \\
$21,000-40,000$ & 18.1 \\
$41,000-60,000$ & 4.3 \\
$61,000-80,000$ & 1.3 \\
$81,000-100,000$ & 0.6 \\
$101,000-120,000$ & 0.1 \\
$121,000+$ Above & 0.3
\end{tabular}

Source: National Bureau of Statistics (2009)

The implication of the data in Table 8 is that, most households in the country ( about $75.2 \%$ ) cannot spend more than $\$ 20,000$ per month on basic necessities such food, shelter and clothing. A person within this income level needs to repay $\$ 8,993.26$ per month (see Table 7) to afford a loan of $\$ 1.5$ to acquire a low-cost residential unit. Such monthly mortgage debt service $(\$ 8,993.26)$ is greater than one-third of the monthly income $(\$ 6,666.67)$. Hence, a loan of $\$ 1.5$ is unaffordable to persons earning $\$ 20,000$ and below in the country. 
Furthermore, based on a maximum repayment to income ratio (RTI) of one-third of the borrower's monthly income, someone seeking to borrow $\$ 1$ million from the NHF with a repayment period of 30 years must earn a minimum of $\$ 18,000$ per month. Similarly, a borrower must earn a minimum of $\$ 27,000$ per month in order to borrow $\$ 1.5$ million. Considering the low income level of households in Nigeria and coupled with widespread income inequality in the country (see Table 8 ), over $70 \%$ of households in the country cannot afford a National Housing Fund loan of $\$ 1.5$ million to purchase or develop a home. The scenario in commercial banks is more worrisome due to high interest rates. Based on data on prime interest rates on real estate loans granted by commercial banks in Nigeria from August, 2008 to July, 2010, the weighted average prime interest rate on real estate loans charged by all banks within the period is $18.14 \%$ as presented in Table 9 . The analysis of the volatility of the interest rates as presented in Table 9 reveal that interest rate risk on real estate loans within the period was lowest in Keystone Bank (formerly Bank PHB) and highest in First Bank.

Table 9: Volatility of Prime Interest Rates on Real Estate Loans Granted by Commercial Banks in Nigeria, 2008 - 2010

\begin{tabular}{|c|c|c|c|}
\hline Bank & $\begin{array}{l}\text { Average Interest } \\
\text { Rate (\%) }\end{array}$ & Interest Rate Risk & $\begin{array}{l}\text { Interest Rate Risk } \\
\text { Ratio }\end{array}$ \\
\hline Access Bank & 19.9 & 2.377 & 0.124 \\
\hline Mainstreet & 16.94 & 2.436 & 0.144 \\
\hline Diamond & 19.06 & 0.899 & 0.047 \\
\hline Ecobank & 18.28 & 2.586 & 0.141 \\
\hline ETBank & 17.00 & 2.646 & 0.156 \\
\hline Fidelity & 16.13 & 1.728 & 0.107 \\
\hline First Bank & 17.50 & 3.969 & 0.227 \\
\hline FCMB & 17.69 & 1.102 & 0.062 \\
\hline FinBank & 19.81 & 1.878 & 0.095 \\
\hline GTBank & 18.00 & 0.866 & 0.048 \\
\hline Stanbic IBTC & 19.06 & 2.794 & 0.147 \\
\hline Intercon'l & 18.56 & 3.657 & 0.197 \\
\hline Citibank & 14.63 & 2.421 & 0.165 \\
\hline Oceanic & 16.31 & 3.176 & 0.195 \\
\hline Keystone & 19.00 & 0.000 & 0.000 \\
\hline Skye Bank & 20.13 & 2.027 & 0.101 \\
\hline Enterprise & 20.50 & 2.031 & 0.099 \\
\hline Stand. Chart & 17.19 & 1.130 & 0.066 \\
\hline Sterling & 20.17 & 2.355 & 0.117 \\
\hline Union Bank & 19.13 & 1.965 & 0.103 \\
\hline UBA & 15.25 & 1.369 & 0.090 \\
\hline Unity & 21.16 & 2.701 & 0.128 \\
\hline Wema Bank & 17.63 & 0.781 & 0.044 \\
\hline Zenith Bank & 16.56 & 2.272 & 0.137 \\
\hline All Banks & 18.14 & 2.806 & 0.155 \\
\hline
\end{tabular}

Source: Computed from CBN (2010)

The annual equivalents of real estate loans based on the average prime interest rate of $18.14 \%$ and expected repayment periods were determined. The annual equivalents were determined using the model: 
Annual Equivalent of Real Estate Loan

$$
\left.=\frac{p\left(\{+i / m)^{m / p}-1(1+i / m)^{m n}\right\}}{\left\{(1+i / m)^{m n}-1\right.}\right\}
$$

where $p=$ number of repayments of loan in a year

$\mathrm{m}=$ number of times interest is compounded on the loan in a year

$\mathrm{i}=$ nominal rate of interest on real estate loan

$\mathrm{n}=$ total number of years for which the loan will be repaid

These annual equivalents were used to determine the affordability level of loan on monthly basis as presented in Table 10.

Table 10: Affordability Level of Real Estate Loans Granted by Commercial Banks based on Weighted Average Interest Rate of $\mathbf{1 8 . 1 4 \%}$

\begin{tabular}{llllll}
\hline \multirow{2}{*}{$\begin{array}{l}\text { Loan Amount } \\
\text { in N" million }\end{array}$} & \multicolumn{5}{c}{ Duration of Loan and Monthly Repayment Amount in N } \\
\cline { 2 - 5 } & 3 years & \multicolumn{3}{c}{ 4years 5 years } & \multicolumn{3}{c}{ 6years } & 7years & \\
\hline 4.00 & $144,890.66$ & $117,792.83$ & $101,878.60$ & $91,548.03$ & $84,399.91$ \\
4.25 & $153,946.33$ & $125,154.88$ & $108,246.01$ & $97,269.78$ & $89,674.90$ \\
2.35 & $85,123.26$ & $69,203.29$ & $59,853.68$ & $53,784.47$ & $49,584.94$ \\
6.0 & $217,336.00$ & $176,689.24$ & $152,817.89$ & $137,322.04$ & $126,599.86$ \\
2.0 & $72,445.33$ & $58,896.41$ & $50,939.30$ & $45,774.01$ & $42,199.95$ \\
1.3 & $47,089.47$ & $38,282.67$ & $33,110.54$ & $29,753.11$ & $27,429.97$ \\
5.5 & $199,224.66$ & $161,965.14$ & $140,083.07$ & $125,878.54$ & $116,049.87$ \\
\hline
\end{tabular}

Source: Computed from Data in Table 9

Comparing data on the distribution of household incomes in Nigeria as presented in Table 8 and that on the affordability level for commercial bank loans in Table 10, over $90 \%$ of households in Nigeria cannot afford mortgage loans from commercial banks in the country based on the affordability benchmark of a maximum monthly repayment to income (RTI) ratio of one-third (33.33 per cent) of the monthly income of the borrower used for loan servicing. For example, a person who earns an income of $\$ 40,000$ per month needs to repay $\$ 47,089.47$ to afford a commercial bank loan of $\$ 1.3$ million, repayable within three years (see Table 10). This mortgage debt service is far above one - third of such monthly income $(\$ 13,333.33)$ which is the minimum affordability level for servicing the loan. Besides, it is also greater than the entire monthly income. Based on data in Table 8, 93.3\% of households in Nigeria earn a monthly income of between $\$ 1,000$ and $\$ 40,000$ and cannot afford commercial bank loan of $\$ 1.3$ million, repayable within a minimum period of three years to acquire a low-cost residential apartment at that amount.

The efficiency of the mortgage market in Nigeria is dependent on the affordability of loanable funds by the different segments of income earners. Mortgage financing in the country can contribute significantly to poverty alleviation only if majority of loan seekers can afford and access mortgage credit for investment purposes at reasonable interest rates. In Nigeria, where over $70 \%$ of the households are living in abject poverty with very low income, it is imperative for mortgage institutions and commercial banks in the country to introduce mortgage arrangements that meet the needs of this segment of the nation's population. This will enhance the social viability of the mortgage system in Nigeria in general and poverty reduction in particular. 
Mortgage financing in Nigeria has not contributed significantly to poverty alleviation due to some constraints, important of which are the Land Use Act of 1978, inefficient land administration system, low level of savings, high interest rates and government budget deficits.

\section{Land Use Act of 1978}

In all intents and purposes, the Land Use Act regulates the ownership, alienation, acquisition, administration and management of land within the Federal Republic of Nigeria. Section 1 of the Act vests all land in the territory of each state in the Federation of Nigeria in the Governor of that state and such land shall be held in trust and administered for the use and common benefit of all Nigerians in accordance with the provisions of the Act. Sections 21 and 22 of the Act prohibit alienation, assignment, mortgage, transfer of possession, sub - lease or otherwise howsoever customary or statutory rights of occupancy in Nigeria without the consent and approval of the Governor of the state where such right of occupancy was granted. A land policy which restricts the citizens' right to mortgage their land as provided in Sections 21 and 22 of the Land Use Act is anti-people and oppressive and cannot enhance the efficiency of the mortgage market.

\section{Inefficient Land Administration System}

Land administration is the process of determining, recording and disseminating information about the tenure, value and use of land, usually by a public agency (Adams, 2006). Nigeria occupies a total land area of 924,768 square kilometres, out of which $20 \%$ are urban lands and $80 \%$ are rural lands. It has been estimated that about $3 \%$ of the $20 \%$ of land in the urban areas of Nigeria is mapped, titled and registered (Ukaejiofo, 2007).This is grossly inadequate to support mortgage transactions in the country.

\section{Low level of savings}

Mortgage and other financial institutions operate through financial intermediation. That is, they mobilize savings and deposits from individuals and corporate bodies and allocate such funds as credit. Thus, the availability of loanable funds is also dependent on the amount of savings mobilized. Given a national absolute poverty rate of $78.3 \%$ (NBS, 2009) and national unemployment rate of $19.7 \%$ ( NBS, 2009), coupled with large family size, most households lack savings. This affects the quantum of loanable funds in the mortgage market.

\section{Unaffordable interest rates}

Interest rate is a critical variable in the loanable funds market, given its role in the mobilization and efficient allocation of financial resources (Alade et al, 2003). Interest rate approved by the Federal Mortgage Bank of Nigeria on NHF loans is 6\%.This has been found to be unaffordable to most households in the country, given the distribution of households' monthly income (see Tables 7 and 8). On the other hand, commercial banks charge an average of between $14.63 \%$ $21.16 \%$. This is quite high and unaffordable to over $90 \%$ of households in the country (see Tables 8, 9 and 10).

\section{Government budget deficits}

Most government budgets in Nigeria are deficit budgets. This affects the supply of and demand for loanable funds (Alade et al, 2003). Most times, these budget deficits are financed by the domestic banking system, thereby reducing the volume of credit available to the private sector. 


\section{CONCLUSION}

Mortgage financing has not contributed significantly to economic growth in Nigeria unlike in other countries. This is evidenced by low mortgage loans and advances to GDP ratio of $0.001 \%$, compared to $50 \%$ in the United States, $60 \%$ in the United Kingdom, 55\% in Europe and 35-40\% in Asia. Similarly, it has not contributed to poverty alleviation and economic empowerment due to poor access to, and unaffordability of available loanable funds by over $70 \%$ of households in the country. However, the mortgage market in the country can be strengthened to act as an instrument for poverty alleviation and economic empowerment. This can be achieved through improving access to mortgage loans by all segments of income earners in the country, with particular attention to the poor, which constitute the largest proportion of the population. Such initiatives should include amendment of obnoxious sections of the Land Use Act, direct government intervention through subsidies and establishment of micro-lending bank for the poor, introduction of pro-poor mortgage facilities into the retail mortgage lending market and adoption of co-operatives approach to mortgage lending.

\section{THE WAY FORWARD}

In order to achieve poverty alleviation and economic empowerment through mortgage financing in Nigeria, loanable funds must be available, accessible and affordable to all groups of income earners in the country at reasonable interest rates. This inevitably requires the amendment of the Land Use Act of 1978, introduction of pro-poor mortgage facilities, the adoption of a co-operative approach to mortgage lending and establishment of micro-lending bank for the poor.

\section{Amendment of the Land Use Act of 1978}

Although progress has been made by the Federal Government towards the amendment of the Land Use Act of 1978, such amendment should enhance the deregulation of land transactions in the country. Hence, Sections 1, 21 and 22 of the Act should be amended without further delay. This will enhance the efficiency of the mortgage market in Nigeria as borrowers would not need to obtain Governor's consent to use their real property as collateral to secure mortgage loan.

\section{Pro-poor mortgage facilities}

Pro-poor mortgage facilities should be introduced for the low income earners to eliminate the present situation in which they are crowded out of the mortgage market by the high income earners. Such facilities should be specifically introduced for a particular group of low income earners such as those who earn below $\$ 50,000$ per month, at very low interest rate. For instance, South Africa has an arrangement similar to this as it grants housing subsidy to persons who earn below R3,500 per month.

\section{Co-operatives approach to mortgage lending}

There is need for adoption of co-operatives approach to mortgage lending instead of the present individualized approach. For this approach to be effective, mortgage loans should be granted through trade, community and faith-based associations. This will minimize default risk, minimize difficulty in securing collateral for the loan, as well as enhance easier identification of the borrowers as the sureties are usually members of the borrower's trade, community or faithbased association. 


\section{Micro-lending bank for the poor}

For mortgage financing to contribute significantly to poverty alleviation and economic empowerment in Nigeria, the government must intervene seriously to support the low income group to access mortgage loans. A micro-lending bank should be established to grant mortgage loans to low income earners based on collateral provided by the government. For example, in Bangladesh, Grameen Bank of Bangladesh was established specifically for banking with the poor in a sustainable way.

\section{REFERENCES}

Adams, M. (2006). Land Reform and Land Administration in Sub - Saharan Africa. (online). Available: www. Icea. Co. Uk/archieve/ICEA Adams La. DA: 14/11/2007.

Adeniji, O. A. (2005). The National Housing Fund Scheme: The Journey so Far. Central Bank of Nigeria Economic and Financial Review.43 (4): 105 - 115.

Adibua, A. (1979). Finance for Housing: A Problematic Issue. Paper presented at the $3^{\text {rd }}$ Annual Conference of the Nigerian Institute of Town Planners held at Benin, Edo State.

Ajanlekoko, J. S. (2001). Sustainable Housing Development in Nigeria: The Financial and Infrastructural Implication. Paper presented at the International Conference on Spatial Information for Sustainable Development, held at Nairobi, Kenya, $2^{\text {nd }}-5^{\text {th }}$ October.

Akinwale, J. A. (2005). Legal and Regulatory Framework for the Mortgage Industry in Nigeria. Central Bank of Nigeria Economic and Financial Review.43 (4): 31- 45.

Alade, S. O.; Ajayi, M.; Enendu, C.I. and Idowu, A. E. (2003). The Supply and Demand of Loanable Funds. In Nnanna, O.J.; Alade, S.O. and Odoko, F.O. (Eds.).Contemporary Economic Policy Issues in Nigeria. Abuja: Central Bank of Nigeria

Arestis, P. and Caner, A. (2009). Capital Account Liberalization and Poverty: How close is the Link? Working PaperNo.4. Cambridge Centre for Economic and Public Policy:

Department of Land Economy, University of Cambridge, England.

Asaju, A. S. (1993). Residential Property Development Financing in a Deregulated Economy: The Nigerian Experience. Journal of the Nigerian Institution of Estate Surveyors and Valuers. 17 (1): 21 - 30.

Central Bank of Nigeria (2005). Statistical Bulletin. Abuja: Central Bank of Nigeria Central Bank of Nigeria (2008). Statistical Bulletin. Fifty Years Anniversary Edition. Abuja: Central Bank of Nigeria

Central Bank of Nigeria (2010). Commercial Banks' Interest Rates and Charges on Loans and Deposits, August 2008 - July, 2010. (online). Available: www. Cenbank.org. DA: 23/07/ 2010.

Chen, S. and Ravallion, M. (2004). How Have the World's Poorest Fared since the Early 1980s? World Bank Research Observer .19(2): 141-170.

Chukwu, C.O. (1997). Elements of Business and Applied Economics. Enugu, NG: Choby Services Ltd.

Ebie, F. (2005). "An X- Ray of the Mortgage Industry in Nigeria." Central Bank of Nigeria Economic and Financial Review.43 (4): 47 - 76. 
Echebiri, R.N. (1997). "The Structure of Income Inequality and Poverty in Rural South-Eastern Nigeria." Proceedings of the Annual Conference of the Nigerian Economic Society. 55-72.

Federal Republic of Nigeria (1978). "The Land Use Decree No. 6, Cap 202." Laws of the Federation of Nigeria. 1990 Edition, Lagos, Nigeria

Federal Republic of Nigeria (1992). National Housing Fund Decree No. 3. Supplement to Official Gazette Extraordinary No.3, Vol.79. p. A8.

FMBN (1997). Five Years of the National Housing Fund. Abuja: Federal Mortgage Bank of Nigeria.

FMBN (2011a). Affordability Table on National Housing Fund. Abuja: Federal Mortgage Bank of Nigeria.

FMBN (2011b, 13 th January). "Nigeria Needs to Build 720,000 Housing Units Annually.” New Nigerian. 14,415: 4

FMBN (2012, 16 ${ }^{\text {th }}$ March). Rejoinder on National Housing Fund. Leadership. 1,669: 12

FOS (1996). Socio-Economic Profile of Nigeria. Lagos: Federal Office of Statistics.

Ifediora, B. U. (2000). Lecture Notes on Estate and Development Finance. Department of Estate Management, University of Nigeria, Nsukka.

IFC (2004). Housing Finance. (online). Available: www.ifc.org/housing finance/why.htm. DA: $19 / 01 / 2011$.

Ifionu, O. J. (1995). An Appraisal of the Performance in Primary Mortgage Finance Institutions in Enugu. MBA Dissertation. Department of Banking and Finance, University of Nigeria, Nsukka.

Igbatayo, S.A. (2001). Poverty, Inequality and Social Exclusion: Strategies for Sustaining Development in Nigeria. In Eruvbetine, A. E. (Ed). The Humanistic Management of Pluralism. Lagos: Murtab Press.

Kajimo-Shakantu, K. and Evans, K. (2006). The Role of Banks in the Provision of Low-Income Housing Finance in South Africa: Can they play a different role? International Journal of Strategic Property Management. 10: 23-38.

Levine, R. and Zervos, S. (1998) .Stock Markets, Banks, and Economic Growth.

American Economic Review. 88(3):537-58

Millington, A. F. (1982). An Introduction to Property Valuation. London: Estates Gazette

NPC (2004). National Economic Empowerment and Development Strategy. Abuja: National Planning Commission.

National Bureau of Statistics (2009). Annual Abstract of Statistics. Abuja: National Bureau of Statistics.

Omotosho, K. (2005). “The Role of the Mortgage Sector in Economic Development.” Central Bank of Nigeria Economic and Financial Review,43 (4): 1 - 30. 
Oni, S. A. (2005). Mortgage Institutions and Financing in Nigeria: Performance Constraints and Prospects. Central Bank of Nigeria Economic and Financial Review.43 (4): 77 - 82.

Rutherford, S. (1999) .The Poor and their Money - An Essay about financial services for the Poor. Institute of Development Policy, Manchester University. January

Sanusi, J.O. (2003). Mortgage Financing in Nigeria: Challenges and Prospects.

Paper Presented at the 9th John Wood Ekpenyong Memorial Lecture, Organized by the Nigerian Institution of Estate Surveyors and Valuers, January 29.

Sowa, N. K. (2002). Financial Sector Reform Policies and Poverty Reduction. Paper presented at the $5^{\text {th }}$ African Economic Research Consortium Senior Policy Seminar held at Dares Salam, Tanzania, February 12 - 14.

Townsend, P. (1973). The Social Minority. London: Allen Lane

Udoekanem, N. B. (2008).Towards Effective Pro - Poor Land Administration in Nigeria: The Challenges and Prospects. In Zubairu, S. N; Morenikeji, O. O; Sanusi, Y. A; Jinadu, A. M. and Ojigi, L.M. (Eds.). Proceedings of the $2^{\text {nd }}$ Annual Conference of the School of Environmental Technology, Federal University of Technology, Minna. 323 - 329.

Udoekanem, N.B. (2009). "Land Policy as a Constraint to Sustainable Housing Delivery in the Niger Delta Region of Nigeria." Ife Journal of Environmental Design and Management. 2(2): 30 39.

Udoekanem, N.B. (2010). “Commercial Banks' Interest Rates on Real Estate Loans and the Implication on Housing Finance in Minna, Nigeria." In Olujimi, J. A. B.; Bello, M. O.; Ojo, E. B.; Olotuah, A. O.; Adebayo, M.A. and Omole, F. K. (Eds.). Proceedings of the 1 st International Conference of the School of Environmental Technology, Federal University of Technology, Akure, Nigeria: $283-290$.

Ukaejiofo, A N. (2007, 17th September). "Perspectives for Reforms of Land Administration in Nigeria." The Guardian, 25 (10, 524): 33.

Winters, A.; McCulloch, N. and McKay, A. (2004). "Trade liberalization and poverty: The evidence so far." \ournal of Economic Literature, 42:72-115.

Zellar, M and Sharma, M. (1998). Rural Finance and Poverty Alleviation. International Food Policy Research Institute (IFPRI). 